\title{
HILDA HILST E AS BUFÓLICAS
}

\section{Hilda Hilst and The Bufólicas}

\author{
Paulo Roberto Sodré*
}

Em alguns estudos ${ }^{1}$ sobre Bufólicas, de Hilda Hilst, livro de poemas lançado em 1992, algumas evidências se põem: 1 . O neologismo bufólicas brinca com o gênero culto pastoril bucólicas, e com a ideia de texto ou desempenho de um bufão, de extração cômico-popular. 2. Os personagens e as situaçóes são oriundos dos contos de fada, tratados parodicamente. 3. A "moral da história", também parodiada ao fim de cada um dos sete poemas, provém das fábulas, cuja fonte mais remota é Esopo. 4. O obsceno a transformar em tetra (em 1992) a trilogia constituída por $O$ caderno rosa de Lori Lamby (1990), Contos d'escárnio. Textos grotescos (1990) e Cartas de um sedutor (1991). Com essas constatações, abreviamos os comentários preliminares sobre o livro e dirigimo-nos pontualmente ao segundo poema de Bufólicas.

\section{Da Careca da Rainha: O Poema}

Sete bufólicas - talvez devêssemos chamar assim os sete textos de Hilda Hilst, em que gêneros diversos são mesclados, como aponta Alcir Pécora (2005) - tratam de sete figuras típicas dos contos de fada: o rei, a rainha, a bruxa, a menina, o anão, a donzela e a fada. Todas essas criaturas, geralmente relacionadas ao bem ou ao mal, traduzem os papéis fundamentais no imaginário do Ocidente, cristalizados nas várias versões dos contos populares. Cada uma dessas figuras, no entanto, é posta pelo avesso, desmascarada, rebaixada pelas práticas sexuais não convencionais ou inesperadas no que diz respeito ao emblema de que cada uma se reveste na tradição.

Dessas sete figuras, duas são homens: o rei, homo-orientado, ou seja, gay, e o anão Cidão, bissexual. Predominam no livro, assim, as mulheres,

* UFES

1 Cf. o levantamento de estudos sobre Hilda Hilst, organizado por Alcir Pécora, nas publicações da autora pela Editora Globo. 
homo e hetero-orientadas. Das cinco, Ula, a rainha careca, é a criatura hilstiana que gostaria de comentar.

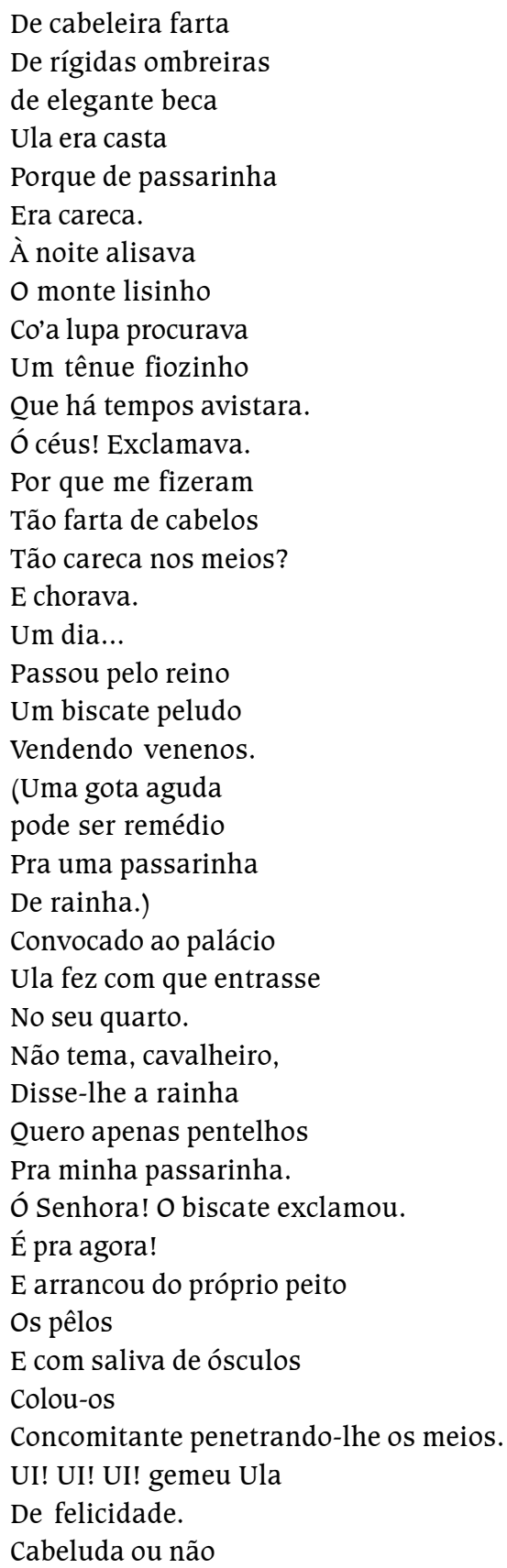




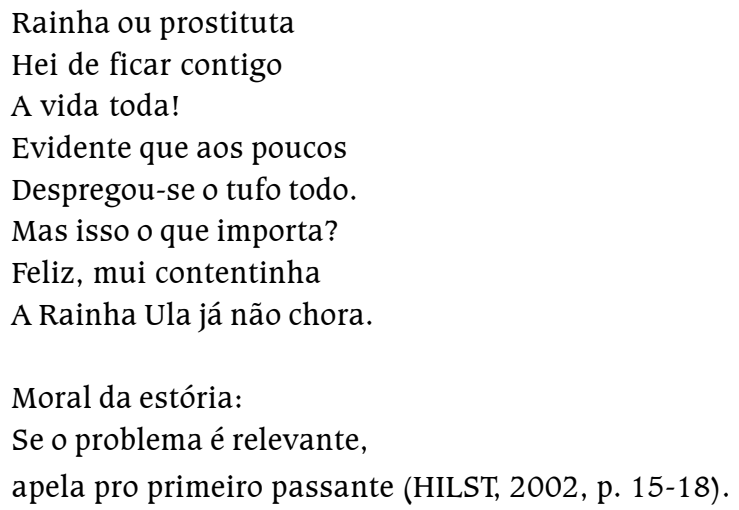

Uma rainha de farta cabeleira com calva passarinha à espera de pentelhos. Cada um desses termos, alguns obscenos ("passarinha”, vagina [ALMEIDA, 1981, p. 197]), cria a dissonância, rompe o horizonte de expectativa criado a respeito de uma rainha. Figura áulica, o título de rainha traz em si o peso do modelo, das convenções sociais, dada sua função paradigmática no reino. Os espelhos dedicados aos reis e a suas mulheres - como o Speculum regum, de Frei Egídio Romano, do século XIII, e o Espelho de Cristina, de Christine de Pisan, do século XV - esmeram-se na cristalização desse papel moral e social, além de político. Apenas para ilustração, no Segundo Livro do Speculum, "en que fabla del gouernamiento dela cana: o dela compañia”, Romano trata do governo das mulheres, dos filhos e dos servos, partindo do suposto de que um bom rei deve sê-lo antes em sua própria casa. A partir do Capítulo VIII, o frei agostiniano discorre sobre matrimônio ("el matrimonio fue ordenado ala generaciõ delos fijos" [ROMANO, 1494, f. lxxxij]), fidelidade feminina ("äev $1 \frac{1}{2}$ guardar fieldad los canados neñalada mente las mugeres alos maridos" [f. lxxxij]), qualidades físicas da mulher ("Las mugeres non nola mente deuen ner apontadas de los bienes del alma: mas aun delos bienes del cuerpo" [f. lxxxvij]), sujeição aos maridos ("las mugeren negid que dize el apontol deu $1 / 2$ ner nubjectas a nus maridos negid que demãdan las leyes del matrimonio" [f. xc]), ou sobre o tempo de gerar filhos ("las mugeres en aquel ti $1 / 2$ po [o frio] nõ mas aparejadas para engendrar. E enno minmo los omes" [f. cxij]). Fiel, bela, servil, fértil e casta, eis o perfil de rainha que se almeja. Evidentemente na contramão dessas expectativas, Hilda Hilst cria Ula, a rainha careca.

Os versos iniciais indicam uma mulher bela, dona de seu papel simbólico, político, moral e social ("De cabeleira farta/ De rígidas ombreiras/ de elegante beca/ Ula era casta”), mas desajustada: era casta, sim, mas "Porque de passarinha/ Era careca". Com essa ressalva, expõe-se o ponto central do poema, o contraste entre a figura régia "casta", de "farta 
cabeleira", e a mulher queixosa por sua "passarinha careca", o que remete o leitor para o equívoco do poema: a rainha Ula não é careca no sentido comum, ou seja, despojada de cabelos na cabeça, ao contrário, sua coma é plena; seu monte de Vênus é que é liso.

É bastante conhecido o sentido social e antropológico dos cabelos presos e dos cabelos soltos nas mulheres. As solteiras deveriam usá-los livres, dado seu estado de virgindade, e as mulheres casadas deveriam usálos presos, dado seu compromisso. Como se sabe, a imagem dos cabelos, sobretudo se fartos, implica tradicionalmente símbolo de feminilidade e energia erótica (LEMAIRE, 1988, p. 147), sentido que atravessa o poema de Hilda Hilst de modo, entretanto, rebaixado (BAKHTIN, 1993, p. 17 et seq.): a cabeleira na parte superior da rainha indica sua abundante energia sexual, seu desejo intenso, mas restrito à imaginação, à ideia (cabeça, parte nobre do corpo humano), uma vez que a realização física do desejo estava travada, vedada pelo fato de sua "passarinha" (genitália ligada, evidentemente, ao baixo corporal [ALBERTI, 1999, p. 50]) ser "careca", destituída, portanto, dos pelos e, por conseguinte, da energia sexual ativa que os cabelos abundantes insinuariam.

Ula, esperando e buscando com lupa, à noite, "Um tênue fiozinho/ Que há tempos avistara", percebe a discrepância no fato de ser "Tão farta de cabelos" e "Tão careca nos meios" e queixa-se, clama pelos "céus", perguntando-lhes a razão de ter sido feita assim. Nesse ínterim, como remédio para a "passarinha", chega o veneno de um biscate: "Um biscate peludo/ Vendendo venenos./ (Uma gota aguda/ pode ser remédio/ Pra uma passarinha/ De rainha.)". A imagem "Uma gota aguda" é a solução poética criativa em que se condensa a ideia de mezinha: a gota (campo semântico de remédio), e de terapia (passe o eufemismo): a gota aguda (referente ao pênis e à penetração que contentarão Ula). A entrada do biscate-cavalheiro na história enfatiza o contraste inicial: o biscate peludo a serviço da rainha careca. 0 "veneno", filtro mágico do amor (como em Ovídio), é o recurso de que se serve o biscate para sanar o problema da calvície da régia "passarinha", cuja dona está interessada apenas, a princípio, em pentelhos. O receio do homem simples, diante de uma senhora em seu quarto no palácio, desfaz-se diante do intento também simples da rainha: "Não tema, cavalheiro,/ Disselhe a rainha/ Quero apenas pentelhos/ Pra minha passarinha./ Ó Senhora! O biscate exclamou./ É pra agora!/ E arrancou do próprio peito/ Os pêlos/ E com saliva de ósculos/ Colou-os/ Concomitante penetrando-lhe os meios". A imagem surpreendente do homem que arranca os pelos do próprio peito, de maneira a sanar a angústia da rainha, alude parodicamente ao mito do pelicano, símbolo cristão: no bestiário medieval, narra-se que essa ave, como Cristo, fere seu corpo para, com seu sangue, salvar seus filhotes da 
morte (MALAXECHEVERRÍA, 1993, p. 52 et seq.). Seus próprios pelos, o biscate os cola ao monte de Vênus com beijos e penetra "os meios" de Ula.

Como se percebe, o clímax dessa bufólica ocorre com o encontro entre a rainha careca Ula e o biscate peludo. É o que se esperaria de uma sátira sobre uma rainha carente. Contudo, ignorando sua "beca elegante", indício de sua posição nobre e convencional, Ula abstrai os papéis femininos alto e baixo, à mão ("Cabeluda ou não/ Rainha ou prostituta"), para ficar com o homem do veneno, dos pelos e dos ósculos ("Hei de ficar contigo/ A vida toda!”). A simplicidade do desejo, a simplicidade da solução e a simplicidade de quem a traz são proporcionais à dificuldade que teria uma rainha de agir, em discursos moralistas: acatar a vontade (tornar presente a cabeleira tanto na cabeça [desejar] como na vulva [concretizar o desejo]), admitir a solução (receber o homem em seu quarto) e despojar-se de seu papel tradicional (acolhendo o biscate, socialmente inferior), deixando de espelhar as virtudes da castidade, da reserva e da dignidade.

A coda ou a estrofe final do poema, em que se expõe a "moral da estória", revela o norte do texto: "Se o problema é relevante,/ apela pro primeiro passante". Toda a convenção relacionada à sofisticação, verniz e idealização das pessoas que desempenham um papel social muito demarcado, cai por terra. Não importa que o que tenha a solução para um problema seja nobre ou plebeu, educado ou tosco, sedentário ou nômade, rei ou biscate. o que importa é o contentamento, é o tufo de pelos arrancado do peito a cobrir uma "passarinha".

Com esse breve comentário sobre o poema "A rainha careca", passo ao que pretendo desenvolver neste estudo: a ideia de comicidade, sua retórica, considerando aspectos da discussão de Vladímir Propp, e seu efeito nas Bufólicas de Hilst, considerando as reflexões de Georges Minois sobre a história do riso.

\section{O Riso E Um Possível Riso HiLstiano}

Desde os primeiros estudos sobre o cômico na expressão literária, patenteia-se a noção de que o risível resulta da exposição de um erro leviano, sem consequências patéticas (ALBERTI, 1999, p. 47). Para Aristóteles, Cícero e seguidores ainda na Antiguidade, no Medievo e nos séculos seguintes, o que deve importar ao escritor satírico é a noção de que a crítica cômica deve, para além da utilidade da correção dos costumes, acompanhar o jogo e o repouso, o agradável ou prazeroso.

A retórica tradicional do riso, sabe-se, inclui estratégias como o trocadilho, o fator surpresa ou a traição da expectativa do leitor, comparações de pessoas com animais, os contrários (ALBERTI, 1999, p. 45-78). Em 
Comicidade e riso, Vladímir Propp procura abranger as diversas maneiras por que se manifesta o cômico na sociedade, em especial pelo riso de zombaria, e aponta algumas: os aspectos físicos, profissionais, a paródia e outras inversões. No que diz respeito especificamente à linguagem verbal e literária, o que nos interessa pontualmente no estudo de Propp, este autor corrobora o que os antigos haviam dito sobre a riqueza de instrumentos de comicidade e zombaria da língua. Destaca três: os trocadilhos, os paradoxos e as tiradas ou chistes (1992, p. 119 et seq.; BERGSON, 1987, p. 57 et seq.). Além desses, chama a atenção para outros aspectos de que destaco o uso dos nomes (p. 129). Estes são engraçados quando insinuam, por oposição (antífrase) ou reforço, um defeito; quando relacionam o homem ou a mulher a um animal ou coisa. Propp afirma ainda que "às vezes os nomes lembram as coisas apenas por assonância, e por isso mesmo sua comicidade sai fortalecida" (p. 131).

O nome da rainha, Ula, requer um exame detido; para tanto, lanço mão do procedimento retórico da interpretatio nominis, a partir do qual se percebe o jogo da poeta (nunca poetisa, como ela afirmava) com o inusitado nome: -ula, sufixo latino formador de diminutivos; assim, Ula significaria "pequena", miúda. No Algarve, em Portugal, ula é substantivo feminino cujo sentido é "grande agitação, correria, confusão" (HOUAISS, 2001, p. 2799). Além dessas acepções ligadas ao sufixo e ao substantivo ula, há ainda outras ligadas a ulo, termo cabível no jogo de Hilst: elemento compositivo grego que significa "gengiva", "cicatriz" e "crespo, anelado"; ademais, ulo é substantivo masculino que significa "queixume de pesar, dor, desgosto; lamento, gemido" (HOUAISS, 2001, p. 2800), ligado, portanto, ao verbo "ulular".

Sabe-se que não é necessário justificar a relação entre o que o texto sugere e o que o autor pretendeu escrever. Entretanto, sabemos da propalada erudição de Hilst, o que torna esse jogo, além de provável, talvez consciente. Nessa brincadeira com o nome, a poeta junta aspectos díspares que compõem bem a figura da rainha: miúda, agitada, com passarinha lisa como gengiva ou cicatriz, carente de anelados ou crespos pentelhos, pelo que lamuria e queixa-se.

O nome Ula implica, assim, diversos sinônimos que lançam a figura da rainha do alto de seu rígido estatuto ("De rígidas ombreiras") para o baixo de sua vulva careca. Esse nome, portanto, não apenas joga com os sentidos da palavra, ele sugere a inversão capital desse poema bufólico: uma rainha que ulula de angústia por sua calva genital. O paradoxo perpassa também o sentido do nome: para uma rainha o ulo contradiz sua posição de modelo feminino, sobretudo se pensarmos na razão que o provoca. Além disso, ao relativizar os papéis femininos e seus modelos (cabeluda ou calva, 
rainha ou prostituta), Ula rompe a expectativa da atuação de uma rainha em se satisfazer com uma aventura sexual qualquer com o biscate - de resto, tema bastante comum na literatura -, para assumir seu contentamento como fêmea e ficar com ele.

Por essa razão, a caricatura ganha matiz na elaboração de Ula. Se o protótipo da rainha que tem seu desejo reprimido inicia o poema (ela é casta), se o tópico da rainha hipócrita que realiza seus desejos com plebeus se ajusta à previsibilidade do que seria cômico, satírico (ela geme de felicidade, ao ceder ao biscate), a atitude de Ula, ao fim do poema, parece, no entanto, surpreender também essas expectativas comuns.

A surpresa (ou contrassurpresa) deve-se ao fato de que predomina em cinco bufólicas o desfecho que normalmente "castiga", endossando a "moral da estória" e respeitando o discurso da sátira tradicional: expor ao ridículo e à humilhação um vício mesquinho, ou seja, que não comove o receptor. Em "O reizinho gay", depois de romper o silêncio a que estava condenado, o membrudo rei e seu reino sucumbiram, virando cinzas; a Chapéu, depois de explorar sua avó Leocádia e Lobão (tornado garoto de programa passivo), descobre a traição dos dois e vê-se trapaceada; o anão Cidão perde seu mastruço; a Cantora Gritante tem sua garganta estuprada pelo jumento e a Filó, fada lésbica, é sequestrada por um "troncudão" e desaparece. Todos esses personagens são estropiados por causa dos dons que de um modo ou outro são benéficos e maléficos para a comunidade por quem atuam: o imenso membro do reizinho gay garantia seu domínio, desde que seu desejo não fosse revelado ("Quero um cu cabeludo!"); o anão dispunha de uma "terceira perna", mas não podia servir-se dela com uma tia nem com um "negão"; a cantora - cujo canto deveria encantar sublimemente o ouvinte - excitava tanto o desejo dos homens que as esposas ficavam inchadas (de dor e assaduras) e raivosas; Filó, a fadinha, deixava uma estrela em quem tocava com seu bastão, alegrando a todos, mas foi levada por um homem troncudo.

As exceções, dentre os castigados, são justamente Ula e Drida. Esta, esfolando velhos, crioulas, gays e patos, segue adiante com a intenção de "encher de traques/ O caminho dos magos./ Com minha espada de palha e bosta seca/ Me voy a Santiago". A rainha e a maga salvam-se de certo castigo moralista das bufólicas e, ao que tudo indica, castigam elas a conveniência social (Ula) e os místicos caminhantes de Santiago de Compostela (Drida), embora a "moral da estória" de Drida (indisfarçável pilhéria com Brida de Paulo Coelho) seja "se encontrares uma maga (antes/ que ela o faça), enraba-a”. Resta saber, contudo, se isso é de fato um castigo para uma maga fixada em analidades. 
Em todas as bufólicas, Hilda Hilst atrela as figuras à paródia e à caricatura, recursos bastante comuns no discurso satírico. Certamente, o fato de o rei ser "viado" (utilizo aqui os termos que normalmente são usados, em negativo, em relação aos que desobedecem à norma da "moral e dos bons costumes"), a menina do chapéu vermelho ser pervertida, a cantora ser ingenuamente excitadora da luxúria e de a fada ser "sapata" implica aparentemente no rebaixamento dos personagens tradicionais e nas situações que os envolvem. Em vez da heterossexualidade procriativa ou da assexualidade, em vez da ingenuidade, da boa intenção, do encantamento ou da boa obra, comuns nos contos de fada e nas fábulas, observa-se o inverso: rei e rainha interessados em "trepar", a menina-cafetina que prostitui Lobão, o anão que quer "transar" (o oposto, portanto, dos sete anões protetores da virgindade de Branca de Neve), a cantora que causa luxúria e a fada que deixa a marca do que parece aludir ao arrombo sodomita causado pelo "troço" da fada ("a estrelinha de cor maravilha/ Fúcsia, bordô/ Ninguém sabia o nome daquela cô").

No entanto, essa obviedade moralista é o ponto górdio do aspecto cômico-satírico das bufólicas hilstianas: ri-se, num primeiro momento, da surpresa, da inversão e do paradoxo em que são postos os personagens. Em observação apressada (e o cômico se desata sobretudo à leitura apressada, carregada de preconceitos), o leitor poderia julgar que a poeta trata de modo moralista das figuras nos poemas. A pergunta, entretanto, emerge: de quem ou de que devemos rir? Do reizinho gay que decide abrir a boca ou dos súditos que perdem sua existência ao ter de enfrentar o desejo do rei? Da rainha careca que chora por uma "passarinha" calva ou de sua decisão de esposar um biscate peludo? Da Chapéu que é traída ou do lobo sodomizado? Do anão que não consegue usar seu mastruço ou da falta de perspicácia do "Senhor" (Deus) a quem o anão fez o pedido de redução do "cacete" descomunal? Da cantora que enfeitiça inadvertidamente ou da comunidade que não reconhece um dom? Da fada lésbica que à noite vira uma fera de troço em riste ou dos vilãos que não a protegem do sequestro do "troncudão"? As respostas escapam à facilidade. Em Bufólicas o mundo está pelo avesso: em vez de cara, mostram-se o falo, a vulva ou o cu (PAZ, 1979, p. 14), de que ainda rimos, mesmo depois de Deus, de o autor e de as ideologias terem perdido seu vigor na sociedade contemporânea.

Observando cada coda de cada bufólica, em que se expõe a "moral da estória", os ridículos não parecem ser o reizinho gay, a rainha careca, Drida, a maga perversa, a Chapéu, o anão triste, a cantora gritante, Filó, a fadinha lésbica. A comunidade, os súditos são os satirizados, por não terem a capacidade de compreender a natureza dos desejos (reizinho gay, rainha careca, Filó); os bem intencionados (cantora gritante) são escarnecidos, por 
não perceberem que o que é bom para uns pode ser nefasto para outros; os crentes (o anão) são malditos, por não desconfiarem da divindade que erra. Sobretudo, satiriza-se o leitor, ainda capaz de se escandalizar, como os súditos dos poemas, diante de gays, de mulheres que desejam claramente ter seu monte de Vênus coberto, de meninas perversas, de erros divinos, de lésbicas. A "moral da estória" da primeira bufólica pode abranger perfeitamente o sentido cômico de todo o livro: "a palavra é necessária/ diante do absurdo". Eis uma das chaves para a compreensão do risível nesses poemas de bufão (ou bufona). A palavra obscena é necessária diante do mundo absurdo, violento, contraditório, estúpido.

Em suas reflexões sobre o riso e o escárnio, Georges Minois pondera que há poucos redutos de sagrado e de seriedade contra os quais vale a pena ainda investir o riso. As seiscentas páginas de sua História do riso e do escárnio mapeiam as concepções de riso desde os gregos aos pósmodernos. No século XX, ao fim do qual Hilda Hilst produziu suas Bufólicas, o humor e o riso colocaram por terra tudo o que encontrou pela frente, dessacralizando-o. Minois sintetiza magistralmente esse processo:

O século XX morreu. Viva o século XXI! O defunto, marcado pelo desencadear de todos os excessos possíveis, não será muito lamentado. Tudo já foi dito sobre esse século e seus horrores. Mas esse século, que custou para morrer, encontrou no riso a força para zombar de seus males, que não foram apenas males de espírito: guerras mundiais, genocídios, crises econômicas, fome, pobreza, desemprego, integrismo, terrorismo, proliferação de pardieiros, ameaças atômicas, degradações do meio ambiente, ódios nacionalistas... Entretanto, de ponta a ponta, uma longa gargalhada ressoou. O riso solto começou aos 14 anos e não cessou mais. Transformou-se num riso nervoso, incontrolável. o mundo riu de tudo, dos deuses, dos demônios e, sobretudo, de si mesmo. O riso foi o ópio do século XX, de Dada aos Monty Pythons. Essa doce droga permitiu à humanidade sobreviver a suas vergonhas. Ela insinuou-se por toda parte, e o século morreu de overdose - uma overdose de riso - quando, tendo este se reduzido ao absurdo, o mundo reencontrou o nonsense original (MINOIS, 2003, p. 553).

Se para Henri Bergson, em 1900, o riso é, antes de tudo, um castigo por meio do qual a sociedade se vinga das "liberdades que se tomaram com ela" (1987, p. 99-100), corroborando a velha máxima da comédia, ridendo castigat mores, para Minois, recenseando tratados e teorias sobre o riso, a sociedade dessacralizada, extraída de seu pedestal de valores e tabus, já não corrige nem se vinga de quem dela se afasta, uma vez que o desvio e a 
diferença tornaram-se senso comum. Rir das "liberdades" que se tomam contra a sociedade significa declarar insensibilidade, ignorância e preconceito contra os "diferentes".

O riso sempre foi desencadeado a partir da observação de um deslocamento. Entretanto, se tudo se tornou, por esse princípio, risível, se a normalidade desapareceu e a rigidez perdeu a razão de ser, o riso não tem como preservar sua força (MINOIS, 2003, p. 605). No mundo contemporâneo, desencantado, a despeito dos guetos de dogma e totalitarismo, "o riso perece pela falta de seriedade. $\mathrm{O}$ que fazia rir era a suposta idiotia dos outros e de suas ideias, de seus comportamentos, a surpresa nascida dos choques culturais. Num mundo onde tudo é respeitável, o componente agressivo do riso foi eliminado; de repente o riso, desvitalizado, não mostra mais os dentes" (MINOIS, 2003, p. 627), uma vez que não rimos mais para castigar os costumes; rimos, sim, para mascarar a perda de sentido de se estar no mundo (p. 632).

Diferentemente, entretanto, do que diagnostica Georges Minois iniludivelmente numa opinião primeiro-mundista, ainda que seu escopo de investigação alcance os pontos cardeais do planeta -, aqui, numa terra onde o tédio europeu e norte-americano só atinge algumas sensibilidades cosmopolitas, o riso ainda tem muito o que "morder". E Hilda Hilst sabia disso.

Em Bufólicas, a epígrafe escolhida é ridendo castigat mores, ilustrada por um desenho de Jaguar, em que um homem peludo (o biscate?) sodomiza uma rainha de língua de fora de tão contente (Ula?). Se originalmente a máxima latina exorta o comediógrafo a castigar pelo riso os costumes considerados ruins, ou seja, imorais, no livro, a epígrafe sofre a inversão, como os personagens e as situações nos poemas: castigar pelo riso os costumes ruins, mas os provincianos, moralistas, reacionários, conservadores.

\section{3. À Guisa de Propedêutica (Se Tanto)}

Numa fábula de Esopo, conta-se a história de um astrônomo que gostava de passear à noite para olhar as estrelas. Certa noite, distraído a olhá-las, caiu num poço. Seus gritos por socorro atraíram a atenção de um homem que passava. Depois de socorrer o astrônomo, o homem pôs-se a ouvir o que havia ocorrido, riu-se dele e lhe disse: Tanto olhou para o céu que acabou por não perceber o que tem debaixo dos pés! Moral da história: É fácil deixar de ver o evidente (ESOPO, 1994, p. 84).

Essa narrativa ilustra de alguma maneira o risco que correm (isto é, corremos) os leitores de Bufólicas e de outras obras obscenas de Hilst: 
mal acostumados com o olhar estrelas e céus, faiscantes de ideal ou espiritualidade, impressionam-se demais com os palavrões e a representação do baixo corporal, perdendo de vista, lamentavelmente, seu tenso sentido poético, e errático.

\title{
RESUMO
}

Comentam-se os poemas-fábula de Bufólicas - em especial o poema "A rainha careca" -, de Hilda Hilst, um dos livros que compõem a produção obscena da autora, considerando aspectos da tradição literária cômica. Examina-se a noção de comicidade seja pelo viés estruturalista de Vladímir Propp, o que enseja uma aproximação estreita com o poema em si, seja pelo viés histórico de Georges Minois, o que propicia uma reflexão sobre o poema e seus arredores contextuais.

Palavras-chave: poesia brasileira contemporânea (Hilda Hilst); Hilda Hilst (poesia); Hilda Hilst (Bufólicas).

\begin{abstract}
This article comments the fable-poems of Bufólicas - namely the poem "A rainha careca" -, one of the obscene books by Hilda Hilst, considering some aspects of the comic in the literary tradition. It investigates the notion of the comic by Vladímir Propp and by Georges Minois studies.

Keywords: Contemporary Brazilian Poetry (Hilda Hilst); Hilda Hilst (Poetry); Hilda Hilst (Bufólicas).
\end{abstract}

\section{REFERÊNCIAS}

ABREU, Caio Fernando. Sobre A obscena senhora D. Disponível em: <http:// www.angelfire.com/ri/casadosol/criticacfa.html>. Acesso em: 28/10/2006.

ALBERTI, Verena. O riso e o risivel na história do pensamento. Rio de Janeiro: Jorge Zahar, 1999.

ALMEIDA, Horácio de. Dicionário de termos eróticos e afins. 2. ed. Rio de Janeiro: Civilização Brasileira, 1981.

AZEVEDo FILHO, Deneval Siqueira de. A poética do neologismo em Bufólicas, de Hilda Hilst. In: Desarraigados: ensaios. Vitória: Ufes, 1995. p. 63-71. 
BAKHTIN, Mikhail. A cultura popular na Idade Média e no Renascimento: o contexto de François Rabelais. 2. ed. Tradução de Yara Frateschi Vieira. São Paulo: Hucitec, 1993.

BERGSON, Henri. O riso: ensaio sobre a significação do cômico. [s. trad.] 2. ed. Rio de Janeiro: Guanabara, 1987.

CUNHA, Antonio Geraldo da. Dicionário etimológico Nova Fronteira da Língua Portuguesa. 2. ed. rev. e acresc. Rio de Janeiro: Nova Fronteira, 1994.

ESOPO. Fábulas. Compilação de Russell Ash e Bernard Higton. Tradução de Heloisa Jahn. São Paulo: Companhia das Letrinhas, 1994.

HILST, Hilda. Bufólicas. São Paulo: Globo, 2002.

HOUAISS, Antônio; VILLAR, Mauro de Salles. Dicionário Houaiss da Língua Portuguesa. Rio de Janeiro: Objetiva, 2001.

LEMAIRE, Ria. Passions et positions: contribuition à une sémiotique du sujet dans la poésie lyrique médiévale en langues romanes. Amsterdam: Rodopi, 1987. Le discours des cantigas de amigo, p. 81-184.

MACHADO, Clara Silveira; DUARTE, Edson Costa. A vida: uma aventura obscena de tão lúcida. Disponível em: <http://www.angelfire.com/ri/casadosol/criticaecd.html>. Acesso em: 28/10/2006.

MALAXECHEVERRÍA, Ignacio (Ed.). Bestiario medieval. Madrid: Siruela, 1993.

MINOIS, Georges. História do riso e do escárnio. Tradução de Maria Elena o. Ortiz Assumpção. São Paulo: Unesp, 2003.

PAZ, Octavio. A metáfora. In:

Conjunções e disjunções. Tradução de Lúcia Teixeira Wisnick. São Paulo: Perspectiva, 1979. p. 9-22.

PÉCORA, Alcir. Hilda Hilst: call for papers. Disponível em: <http:// www.germinaliteratura.com.br/enc_pecora_ago5.htm>. Acesso em: 28/10/2006.

PROPP, Vladímir. Comicidade e riso. Tradução de Aurora Fornoni Bernardini e Homero Freitas de Andrade. São Paulo: Ática, 1992. (Série Fundamentos, v. 84).

QUEIRÓZ, Vera. o guardião do mundo. In: Hilda Hilst: três leituras. Florianópolis: Mulheres, 2000. p. 17-40.

ROMANO, Egidio. Regimiento de los principes. Traducción de Juan Garcia de Castrojeriz. Sevilla: Meinardo Ungut/Estanislao Polono, 1494.

Enviado em: 22/10/2009

Aceito em: 27/01/2010 